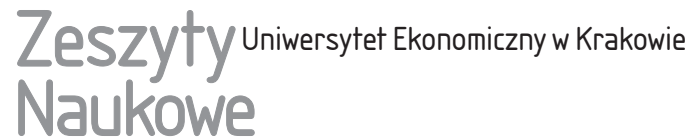

6(930)

ISSN 1898-6447

Zesz. Nauk. UEK, 2014; $6(930):$ 149-162

DOI: 10.15678/ZNUEK.2014.0930.0610

\author{
Monika Musiat-Malagó \\ Katedra Gospodarki Regionalnej \\ Uniwersytet Ekonomiczny w Krakowie
}

\section{Sytuacja planistyczna w województwie małopolskim}

\section{Streszczenie}

Planowanie przestrzenne jest głównym instrumentem polityki przestrzennej. Aktywna polityka pozwala na określenie kierunków zagospodarowania przestrzennego, celów polityki przestrzennej oraz sposobów ich realizacji. Polityka przestrzenna prowadzona przez gminy od 1995 r. daje możliwość zarządzania jednostką terytorialną w sposób kompleksowy. Kompleksowe podejście władz lokalnych do zarządzania gminą przy współpracy ze społecznością lokalną pozwala na osiągnięcie przez gminę trwałego i zrównoważonego rozwoju. Podstawowym aktem prawnym regulującym sprawy planowania przestrzennego w Polsce jest Ustawa z dnia 27 marca 2003 r. o planowaniu i zagospodarowaniu przestrzennym. Zgodnie z jej zapisami system planowania przestrzennego jest realizowany na trzech poziomach: gminy, województwa i kraju. Głównym podmiotem, który odpowiada za zarządzanie przestrzenią, jest gmina. Na poziomie gminy na system aktów planowania i zagospodarowania przestrzennego składają się: studium uwarunkowań i kierunków zagospodarowania przestrzennego oraz miejscowy plan zagospodarowania przestrzennego.

W artykule zaprezentowano postęp w zakresie posiadania przez władze lokalne województwa małopolskiego miejscowych planów zagospodarowania przestrzennego. Obszar analizy objął 182 gminy leżące w granicach administracyjnych województwa. W pracy posłużono się badaniami statystycznymi zamieszczonymi w przygotowywanym corocznie Raporcie o stanie $i$ uwarunkowaniach prac planistycznych $w$ gminach, opracowywanym przez Instytut Geografii i Przestrzennego Zagospodarowania PAN.

Badania dotyczące stanu zagospodarowania przestrzennego w gminach województwa małopolskiego przeprowadzono dla dwóch okresów. Pierwszy horyzont czasowy, tj. 2004 r., związany jest z rozpoczęciem gromadzenia przez Ministerstwo Infrastruktury danych o stanie zagospodarowania przestrzennego $\mathrm{w}$ gminach, drugi odnosi się do ostatniego dostępnego badania z informacjami za $2011 \mathrm{r}$. 
Słowa kluczowe: planowanie przestrzenne, miejscowy plan zagospodarowania przestrzennego, studium uwarunkowań i kierunków zagospodarowania przestrzennego, województwo małopolskie.

\section{Wprowadzenie}

Podstawowym aktem prawnym regulującym sprawy planowania przestrzennego w Polsce jest Ustawa z dnia 27 marca 2003 r. o planowaniu i zagospodarowaniu przestrzennym. Obecnie obowiązujący system planowania przestrzennego zgodnie z tą ustawą jest trójszczeblowy, co oznacza, że zadania ustawowe realizowane są na każdym poziomie podziału administracyjnego kraju, tj. krajowym, wojewódzkim i gminnym, z pominięciem samorządu powiatowego. Należy zaznaczyć, że samorząd powiatowy nie otrzymał żadnych kompetencji dotyczących planowania i zagospodarowania przestrzennego. Dokumenty opracowywane na poziomie powiatu nie mają istotnego wpływu na przestrzeń w wymiarze lokalnym i ponadlokalnym, ponadto ich ustalenia nie mają charakteru wiążącego w trakcie opracowywania aktów planistycznych przez gminę oraz samorząd województwa. Stanowią one jedynie wolne opinie wyrażane przez przewodniczącego zarządu powiatu (starostę) w zakresie polityki przestrzennej i mogą być uwzględniane przez władze gminy i samorząd województwa [Niewiadomski 2009].

Zgodnie z zapisami ustawy o planowaniu i zagospodarowaniu przestrzennym głównym podmiotem, który odpowiada za zarządzanie przestrzenią, jest gmina. Podstawowymi instrumentami służącymi do realizacji polityki przestrzennej i zagospodarowania przestrzennego na jej terenie jest studium uwarunkowań i kierunków zagospodarowania przestrzennego oraz miejscowe plany zagospodarowania przestrzennego.

Celem artykułu jest ocena stanu zaawansowania prac planistycznych na terenie gmin województwa małopolskiego. Badania przeprowadzono na podstawie danych zamieszczonych w przygotowywanym corocznie Raporcie o stanie $i$ uwarunkowaniach prac planistycznych $w$ gminach, opracowywanym przez Instytut Geografii i Przestrzennego Zagospodarowania PAN.

Badania dotyczące stanu zagospodarowania przestrzennego w gminach województwa małopolskiego przeprowadzono dla dwóch okresów. Pierwszy horyzont czasowy, tj. 2004 r., związany jest w rozpoczęciem gromadzenia przez Ministerstwo Infrastruktury danych o stanie zagospodarowania przestrzennego w gminach, drugi odnosi się do ostatniego dostępnego badania $\mathrm{z}$ informacjami za 2011 r. 


\section{System planowania przestrzennego w Polsce}

Podstawę systemu aktów planistycznych państwa stanowi Koncepcja przestrzennego zagospodarowania kraju, za której pośrednictwem państwo kształtuje politykę przestrzenną kraju. Jest to najważniejszy dokument dotyczący ładu przestrzennego Polski. Określa on uwarunkowania, cele i kierunki zrównoważonego rozwoju kraju oraz działania niezbędne do jego osiągnięcia [Ustawa z dnia 27 marca 2003 r. ..., art. 47, ust. 2]. Celem strategicznym określonym w koncepcji jest efektywne wykorzystanie przestrzeni kraju, jej zróżnicowanych potencjałów rozwojowych do osiągnięcia m.in. konkurencyjności, zwiększenia zatrudnienia i większej sprawności państwa oraz spójności społecznej, gospodarczej i przestrzennej w długim horyzoncie czasowym.

Na szczeblu województwa sporządzane są i uchwalane przez sejmik samorządowy województwa plany zagospodarowania przestrzennego województwa. Plan zagospodarowania przestrzennego województwa określa zasady struktury przestrzennej województwa. Zgodnie z Ustawą z dnia 27 marca 2003 r. o planowaniu i zagospodarowaniu przestrzennym $\mathrm{w}$ dokumencie tym określa się cele i kierunki polityki przestrzennej samorządu województwa. Najważniejsze elementy planu zagospodarowania przestrzennego województwa sprowadzają się do określenia w dokumencie [Ustawa z dnia 27 marca 2003 r. ..., art. 39, ust. 3]:

- podstawowych elementów sieci osadniczej województwa, ich powiązań komunikacyjnych oraz infrastrukturalnych,

- systemu obszarów chronionych występujących na terenie województwa,

- rozmieszczenia inwestycji celu publicznego o znaczeniu ponadlokalnym,

- obszarów problemowych,

- obszarów wsparcia,

- obszarów narażonych na niebezpieczeństwo powodzi,

- granic terenów zamkniętych i ich stref ochronnych,

- obszarów występowania udokumentowanych złóż kopalin.

Plany zagospodarowania województwa powinny być spójne z Koncepcją przestrzennego zagospodarowania kraju.

Na szczeblu gminy opracowywane są dwa dokumenty, tj.:

- obligatoryjne studium uwarunkowań i kierunków zagospodarowania przestrzennego gminy, sporządzane zawsze dla obszaru w granicach administracyjnych gminy [Śleszyński i in. 2007],

- miejscowy plan zagospodarowania przestrzennego.

Studium uwarunkowań i kierunków zagospodarowania przestrzennego gminy jest aktem planowania ogólnego o charakterze wewnętrznym, tzw. aktem kierownictwa wewnętrznego. Jest dokumentem wiążącym swymi postanowieniami radę i wójta (burmistrza, prezydenta miasta), którzy przez jego uchwalenie zobowiązują 
się do działań skierowanych na realizację zapisanych w nim ustaleń. Rola studium sprowadza się do koordynacji działań w sferze przestrzennej polityki gminy. Na poziomie studium przejmowane są do gminy najważniejsze cele polityki przestrzennej wyodrębnione w skali ponadlokalnej. Studium pełni również funkcję informacyjną dla inwestorów w zakresie programu rozwoju przestrzennego i gospodarczego. Podsumowując, można stwierdzić, że studium:

- jest aktem polityki przestrzennej gminy,

- koordynuje ustalenia miejscowych planów zagospodarowania przestrzennego,

- stanowi materiał promujący gminę.

Drugim dokumentem opracowywanym na szczeblu gminnym jest miejscowy plan zagospodarowania przestrzennego. Można go uznać za podstawowy dokument regulujący gospodarkę przestrzenną gminy, gdyż ma charakter prawa powszechnie obowiązującego na terenie gminy. Plany są aktami prawa miejscowego, a ich uchwalenie wywołuje skutki finansowe w stosunku do właścicieli nieruchomości, których przeznaczenie zostało w planie zmienione [Markowski i Zuber 2011, s. 184-185]. Plany miejscowe sporządzane są dla całego obszaru gminy lub na określonych w uchwale rady gminy fragmentach terenu położonego w granicy gminy. Ustala się w nim przeznaczenie (funkcję i sposób użytkowania) terenów, określa zasady zagospodarowania i zabudowy oraz rozmieszczenie inwestycji celu publicznego. Dokonuje się tego stosownie do polityki przestrzennej gminy ustalonej w studium, z którą plan musi zachować zgodność [Ustawa z dnia 27 marca 2003 r. ..., art. 14, ust. 1].

W przypadku braku miejscowego planu zagospodarowania przestrzennego określenie sposobów zagospodarowania i warunków zabudowy terenu następuje w drodze decyzji o warunkach zabudowy i zagospodarowania terenu wydawanej na podstawie przepisów odrębnych [Ustawa z dnia 27 marca 2003 r. ..., art. 4, ust. 2].

Ustawodawca dokonał podziału decyzji na dwie kategorie, w zależności od rodzaju inwestycji, której dotyczą, tj. [Raport o stanie miasta 2011, s. 27-28]:

- lokalizację inwestycji celu publicznego, którą ustala się w drodze decyzji o ustaleniu lokalizacji inwestycji celu publicznego (ULI),

- sposób zagospodarowania terenu i warunki zabudowy dla pozostałych inwestycji, które ustala się w drodze decyzji o warunkach zabudowy (WZ).

Decyzja taka jest aktem indywidualnym, regulującym prawnie stosunki między organem a określoną jednostką (adresatem decyzji). Decyzja jest więc kierowana indywidualnie do określonej osoby fizycznej lub prawnej, która jest wnioskodawcą. Jest ona wymagana w każdym przypadku, w którym ustawa Prawo budowlane określa obowiązek uzyskania pozwolenia na budowę. 


\section{Stan zagospodarowania przestrzennego $\mathrm{w}$ gminach województwa małopolskiego}

Obszar badawczy obejmuje 182 gminy położone w granicach administracyjnych województwa małopolskiego. Wśród gmin województwa zidentyfikowano 121 gmin wiejskich, 47 miejsko-wiejskich oraz 11 gmin miejskich, w tym trzy miasta na prawach powiatu, tj. Kraków, Tarnów i Nowy Sącz.

Na koniec 2004 r. tylko 18 samorządów nie posiadało studium uwarunkowań i kierunków zagospodarowania przestrzennego (uikzp) gminy. Pozytywne jest to, że w tychże gminach trwały prace aktualizacyjne nad dokumentem. Należy również zaznaczyć, że spośród wszystkich gmin województwa nie znalazła się ani jedna gmina, która nie posiadałaby studium i nie przystąpiła również do jego sporządzania (tabela 1).

Z kolei na koniec 2011 r. spośród 182 gmin województwa 128 z nich posiadało obowiązujące studium, tj. 70,3\%, a 52 gminy posiadały studium, ale było ono w trakcie zmiany. Jedynie dwie gminy, tj. Słaboszów w powiecie miechowskim i Koniusza w powiecie proszowickim, nie posiadały studium, nie przystąpiły one również do jego sporządzenia.

W gminach województwa małopolskiego na koniec 2004 r. powierzchnia terenów wskazanych w studiach uikzp do sporządzenia miejscowych planów zagospodarowania przestrzennego (mpzp) wynosiła 1028226 ha, co stanowiło 67,7\% powierzchni województwa małopolskiego. Z kolei na koniec 2011 r. powierzchnia terenów wskazanych w studiach uikzp do sporządzenia miejscowych planów zagospodarowania przestrzennego wynosiła o 317319 ha mniej w stosunku do analizowanego 2004 r. Udział powierzchni tychże terenów zmniejszył się zatem o 30,9\%. Największy odsetek terenów wskazanych w studium do sporządzenia planów miejscowych w 2011 r. wynosił w gminach wiejskich 33,3\% (tabela 1).

W studiach uikzp do zmian przeznaczenia gruntów rolnych i leśnych na inne cele w 2004 r. przewidziano ogółem 24216 ha. Na koniec 2011 r. wyznaczone w studium obszary wymagające zmian przeznaczenia gruntów rolnych i leśnych na inne cele wzrosły o 4089 ha i wyniosły ogółem 28305 ha.

O zakresie działań planistycznych świadczy w istotnym stopniu liczba obowiązujących w danym roku miejscowych planów zagospodarowania przestrzennego. Według danych dostępnych w raportach w końcu 2004 r. na terenie województwa małopolskiego obowiązywało 1520 miejscowych planów zagospodarowania przestrzennego uchwalonych na podstawie obydwu ustaw (w tym 116 na podstawie aktu z 2003 r.). Z tej liczby 796 planów dotyczyło powierzchni gmin wiejskich, 545 - gmin miejsko-wiejskich, 111 - gmin miejskich, a 68 obowiązujących planów posiadały łącznie miasta na prawach powiatu (tabela 2). 


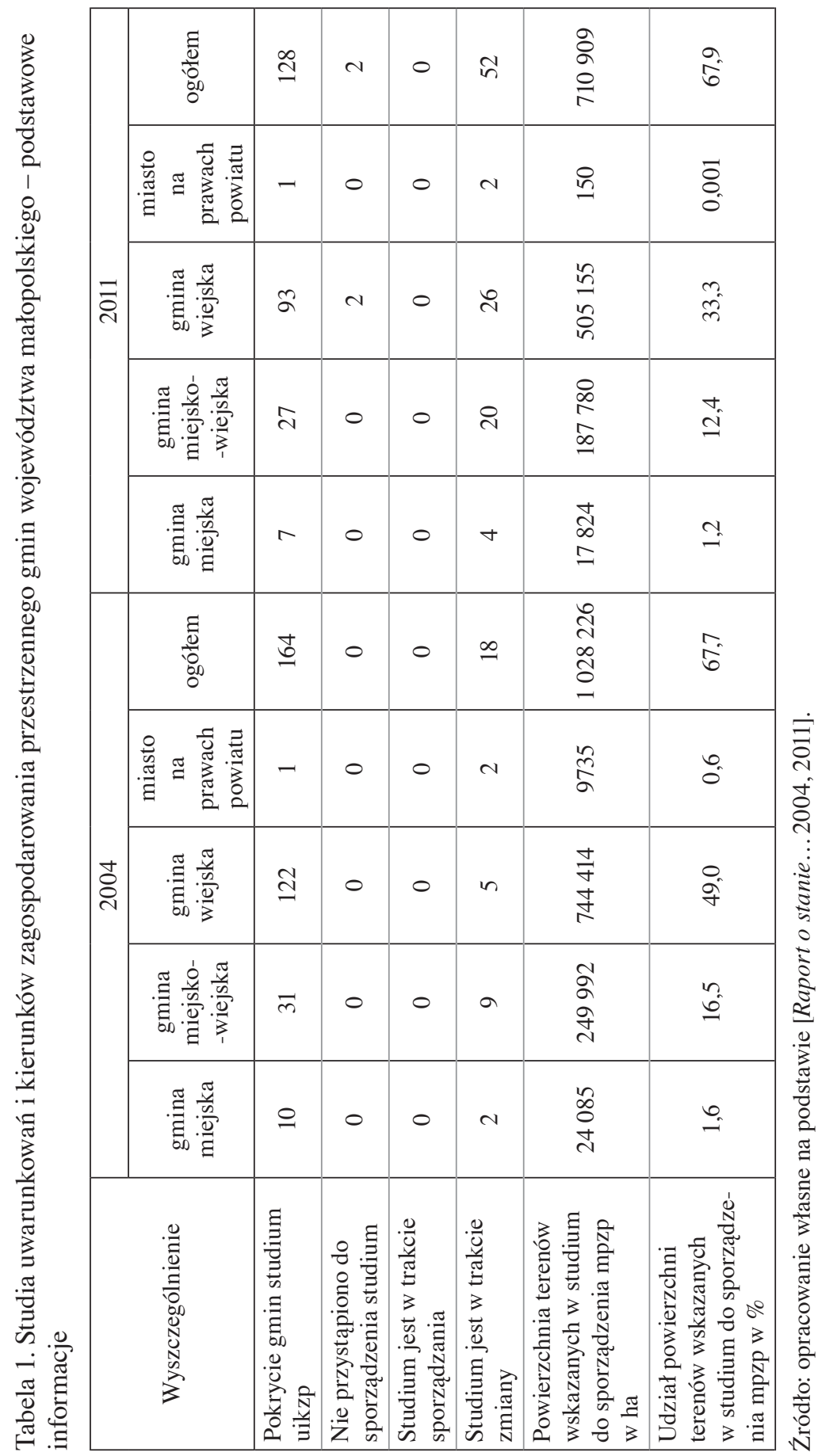




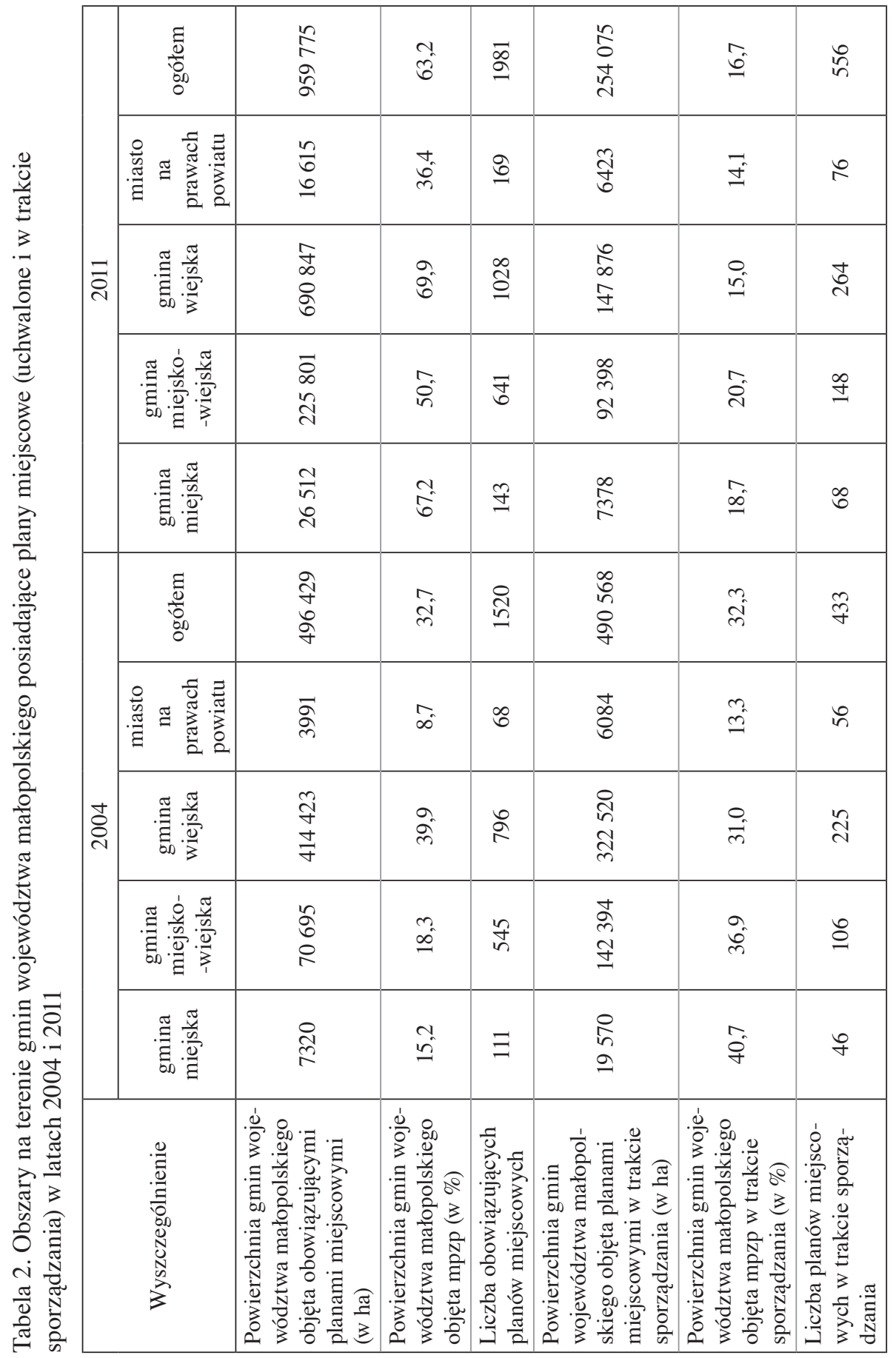




\begin{tabular}{|c|c|c|c|}
\hline \multirow{5}{*}{$\overline{\vec{\nu}}$} & $\frac{E}{0}$ & $\begin{array}{l}\stackrel{2}{N} \\
\text { N }\end{array}$ & $\frac{g}{\sqrt{n}}$ \\
\hline & 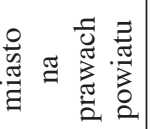 & $\underset{0}{\mathscr{0}}$ & - \\
\hline & 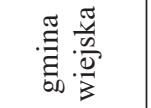 & $\begin{array}{l}\hat{\hat{s}} \\
\text { 옹 }\end{array}$ & $\vec{n}$ \\
\hline & 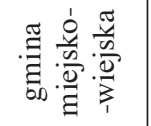 & $\begin{array}{l}\stackrel{m}{\vartheta} \\
\infty\end{array}$ & $\stackrel{\infty}{\varrho}$ \\
\hline & 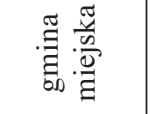 & 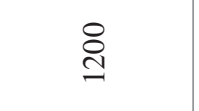 & શે \\
\hline \multirow{6}{*}{ ఫั } & 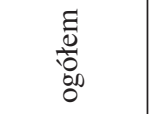 & $\begin{array}{l}\stackrel{2}{\ddots} \\
\stackrel{n}{n}\end{array}$ & ন্ \\
\hline & 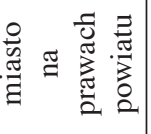 & 总 & - \\
\hline & 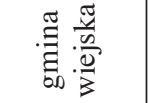 & $\begin{array}{l}8 \\
\infty \\
=\end{array}$ & $\stackrel{ \pm}{\text { 工 }}$ \\
\hline & 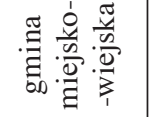 & $\underset{\substack{\text { I } \\
\text { I }}}{ }$ & 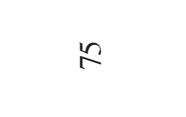 \\
\hline & 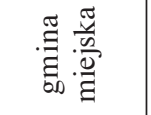 & $\stackrel{\curvearrowright}{m}$ & - \\
\hline & 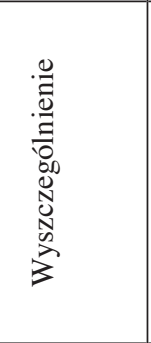 & 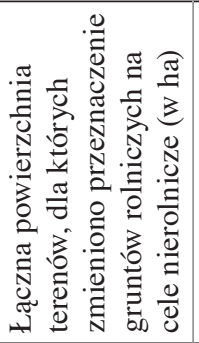 & 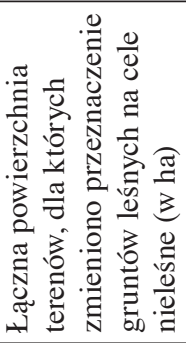 \\
\hline
\end{tabular}


W 2004 r. na obszarze województwa małopolskiego zidentyfikowano 139 gmin, tj. ponad 76\%, które w swoich granicach administracyjnych legitymowały się brakiem dokumentów z zakresu planowania przestrzennego w randze prawa miejskiego. Pozostałe 43 gminy badanego województwa posiadały plany miejscowe, w tym szczególnie dominowały gminy wiejskie. Spośród wszystkich gmin wiejskich województwa małopolskiego $26 \%$ gmin posiadało tego rodzaju opracowania.

Najwięcej planów miejscowych posiadały gminy powiatu nowosądeckiego (51 planów), zaś na terenie czterech powiatów, tj. dąbrowskiego, miechowskiego, oświęcimskiego i tatrzańskiego, żadna gmina nie posiadała miejscowego planu zagospodarowania przestrzennego (łącznie 28 gmin).

W 2004 r. na terenie województwa małopolskiego znalazło się 16 gmin, w których obwiązujące plany miejscowe obejmowały swym zasięgiem cały obszar gminy $(100 \%)$, co stanowiło zaledwie ok. 9\% wszystkich gmin w województwie małopolskim. W opozycji do tych jednostek na terenie tego regionu zidentyfikowano 11 gmin, które pod względem powierzchni zajmowanej przez plany miejscowe nie przekraczały $10 \%$ powierzchni gmin. Gminy te stanowiły $6 \%$ jednostek terytorialnych województwa małopolskiego. Wśród gmin z tej grupy znalazło się sześć o najmniejszej powierzchni objętej planami zagospodarowania przestrzennego, tj. niespełna 1\%. Były to trzy gminy miejsko-wiejskie, tj. Olkusz, Wolbrom i Piwniczna, oraz trzy gminy wiejskie, tj. Zielonki, Radłów i Stryszowa.

Na koniec 2011 r. w województwie małopolskim obowiązywało 1981 miejscowych planów zagospodarowania przestrzennego, czyli o 461 planów więcej niż w 2004 r. W sumie na obszarze województwa małopolskiego największą liczbę planów miejscowych posiadały gminy wiejskie, tj. ok. 52\% wszystkich obowiązujących planów miejscowych dla gmin województwa małopolskiego (tabela 2). Należy jednak zaznaczyć, że największy wzrost liczby planów miejscowych miał miejsce w miastach na prawach powiatu.

Całkowita powierzchnia pokryta planami miejscowymi w gminach województwa małopolskiego wzrosła prawie dwukrotnie w stosunku do analizowanego 2004 r. i wynosiła 959775 ha. Od momentu wejścia w życie ustawy o planowaniu i zagospodarowaniu przestrzennym z 2003 r. małopolskie gminy sukcesywnie wprowadzają plany miejscowe. Na przestrzeni badanego okresu widoczny jest znaczny wzrost powierzchni objętej sporządzonymi planami w powierzchni województwa z 32,7\% w 2004 r. do 63,2\% w 2011 r.

W 2011 r. 25 gmin województwa małopolskiego określiło stopień pokrycia swojego terytorium planami miejscowymi do 5\%, zatem odsetek samorządów, które posiadały plany miejscowe dla mniej niż $5 \%$ powierzchni swojego obszaru, wyniósł ok. 14\%. Z kolei udział samorządów z dokumentami o charakterze prawa miejscowego opracowanymi dla ponad $90 \%$ powierzchni gmin Małopolski 
wyniósł 57\%. Świadczy to o znacznych postępach w planowaniu miejscowym i uporządkowaniu gospodarki przestrzennej gmin. Wciąż jednak istniały gminy, które nie posiadały planów miejscowych. W 2011 r. odnotowano na terenie Małopolski 15 gmin, tj. 8\%, które nie posiadały takiego opracowania. Wśród nich znalazło się pięć gmin miejsko-wiejskich, były to Proszowice i Nowe Brzesko w powiecie proszowickim, Czchów w powiecie brzeskim oraz Ciężkowice i Żabno w powiecie tarnowskim. Pozostałe 10 gmin były to jednostki o statusie administracyjno-prawnym wiejskim. Najwięcej planów w 2011 r. - podobnie jak w 2004 r. - skupiały na swoim terenie gminy powiatu nowosądeckiego (415 planów), najmniej zaś - gminy w powiecie proszowickim (tylko cztery plany). W 2004 r. województwo małopolskie liczyło 433 miejscowych planów zagospodarowania przestrzennego w trakcie sporządzania, w tym gminy miejskie - 46 planów, wiejskie - 225 planów, miejsko-wiejskie - 106 planów, zaś miasta na prawach powiatu - 56. Powierzchnia województwa objęta planami w fazie projektowej wyniosła $490568 \mathrm{ha}, \mathrm{tj} .32,3 \%$ powierzchni województwa. W poszczególnych gminach wskaźnik ten wynosił (tabela 2):

- w gminach miejskich - 19570 ha,

- w gminach miejsko-wiejskich - 142394 ha,

- w gminach wiejskich - 322520 ha,

- w miastach na prawach powiatu - 6084 ha.

W końcu 2011 r. w gminach województwa małopolskiego w fazie projektowej znalazło się 556 mpzp. Powierzchnia województwa objęta planami zagospodarowania przestrzennego w trakcie sporządzania w 2011 r. jest o 123 ha większa od sumy powierzchni planów będących w trakcie sporządzania w 2004 r. (wzrost o 28,4\%). Należy jednak zaznaczyć, że wskaźnik powierzchni planów miejscowych projektowanych nie oznacza wzrostu całkowitej powierzchni objętej obowiązującymi planami, gdyż plany w trakcie sporządzania mogą obejmować części istniejących już planów miejscowych.

Zmiany przeznaczenia gruntów rolnych i leśnych na cele nierolnicze i nieleśne świadczą o planowanych kierunkach rozwoju i inwestycji w gminach. Ogółem w skali województwa łączna powierzchnia gruntów rolnych, dla których zmieniono w planach przeznaczenie na cele nierolnicze, wyniosła w 2011 r. 72299 ha i wzrosła w stosunku do 2004 r. prawie pięciokrotnie. Najwięcej terenów odrolnionych w stosunku do powierzchni znajdowało się w gminach wiejskich (tabela 2). Z kolei łączna powierzchnia gruntów leśnych, dla których zmieniono w planach przeznaczenie na cele nieleśne, wyniosła w 2011 r. 5149 ha, z czego również najwięcej przypadało na gminy wiejskie (4951 ha).

Według danych Raportu o stanie i uwarunkowaniach prac planistycznych $w$ gminach [2011] w 2011 r. zostało wydanych na terenie gmin województwa małopolskiego 8289 decyzji o warunkach zabudowy i zagospodarowania terenu. 


\begin{tabular}{|c|c|c|c|c|c|}
\hline \multirow{5}{*}{$\overline{\bar{c}}$} & $\frac{\Xi}{0}$ & $\begin{array}{l}\text { के } \\
\text { ఎ }\end{array}$ & 突 & $\overline{\mathrm{a}}$ & $\begin{array}{l}\infty \\
\stackrel{N}{i}\end{array}$ \\
\hline & . & $\begin{array}{l}\infty \\
\stackrel{0}{0} \\
\text { ㄱ }\end{array}$ & $\frac{0}{n}$ & $\underset{+}{\infty}$ & $\stackrel{+}{\sigma}$ \\
\hline & 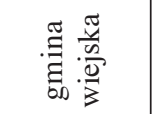 & 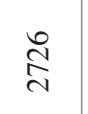 & 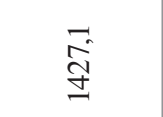 & $\underset{\sim}{\vec{J}}$ & $\underset{\substack{n \\
\infty}}{\stackrel{n}{n}}$ \\
\hline & 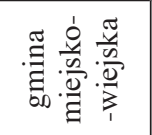 & 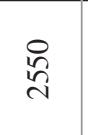 & $\begin{array}{l}\text { m. } \\
\infty \\
\infty \\
\infty\end{array}$ & 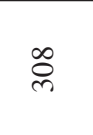 & $\begin{array}{l}\infty \\
\frac{\infty}{m}\end{array}$ \\
\hline & 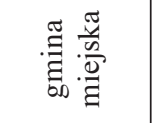 & $\stackrel{\wp}{q}$ & $\frac{M}{\mathrm{I}}$ & $\bar{\sigma}$ & $\stackrel{m}{\hat{\sim}}$ \\
\hline \multirow{5}{*}{$\begin{array}{l}\text { ঠ } \\
\text { ঠ }\end{array}$} & $\frac{E}{00}$ & $\begin{array}{l}n \\
8 \\
\pm \\
\pm\end{array}$ & . & 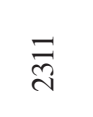 & . \\
\hline & 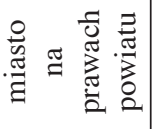 & $\stackrel{\widetilde{m}}{\stackrel{m}{\sim}}$ & . & ญ઼ & . \\
\hline & 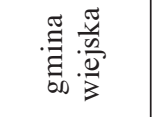 & $\hat{n}$ & . & ซึ & . \\
\hline & 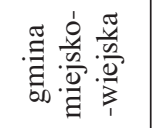 & 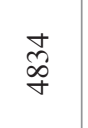 & . & $\stackrel{m}{r}$ & . \\
\hline & 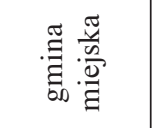 & $\stackrel{n}{\infty}$ & . & & . \\
\hline & 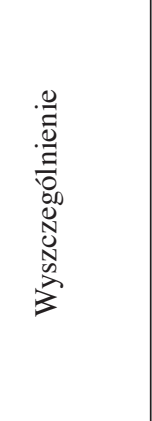 & 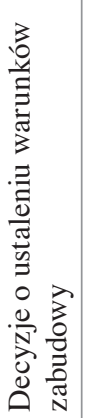 & 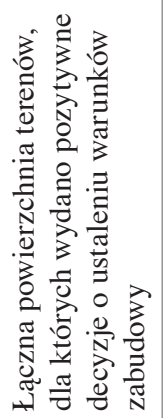 & 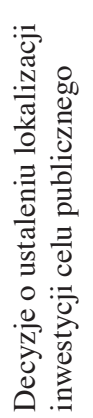 & 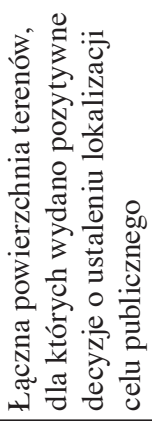 \\
\hline
\end{tabular}


W analizowanym okresie liczba wydanych decyzji zmalała prawie dwukrotnie. W 2011 r. na terenie gmin województwa wydano łącznie o 6315 decyzji o warunkach zabudowy i zagospodarowania terenu mniej niż w 2004 r. Łączna powierzchnia terenów, dla których wydano pozytywne decyzje o ustaleniu warunków zabudowy, wyniosła w 2011 r. 2527,7 ha. Najwięcej wydanych decyzji o ustaleniu warunków zabudowy (tzw. wuzetki) miało miejsce w gminach wiejskich (2726), a następnie w miastach na prawach powiatu (2608), najmniej zaś - w gminach miejskich (405). Spośród wszystkich decyzji najwięcej - bo aż 5420, dotyczyło zabudowy mieszkaniowej jednorodzinnej (rys. 1).

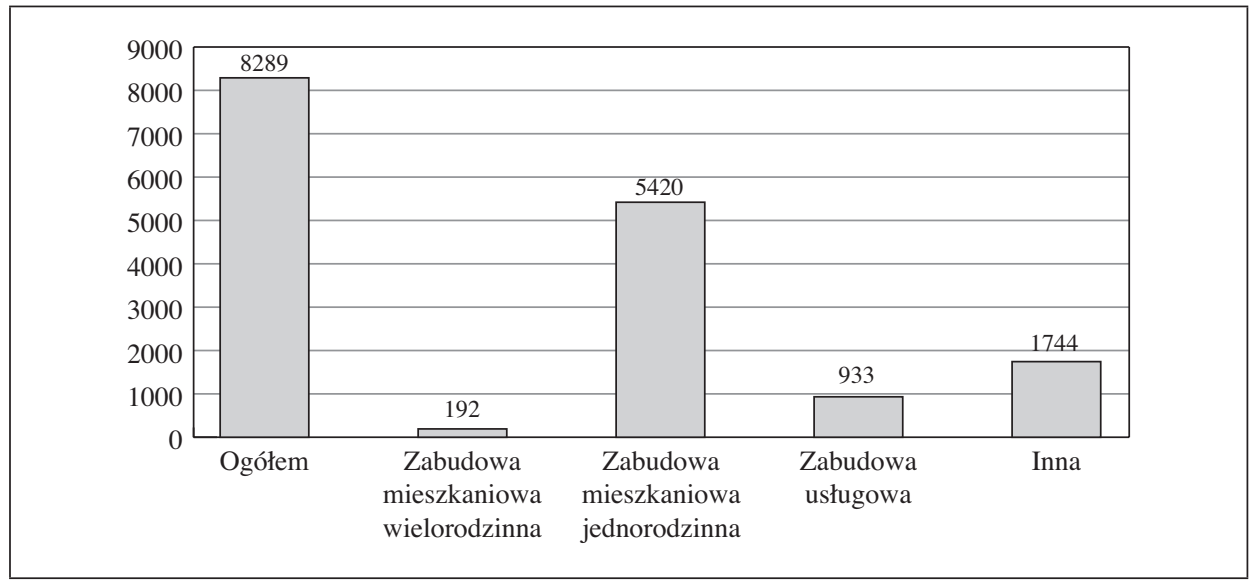

Rys. 1. Liczba wydanych decyzji o warunkach zabudowy w gminach województwa małopolskiego w $2011 \mathrm{r}$.

Źródło: opracowanie własne na podstawie [Raport o stanie... 2011].

W 2011 r. na obszarze gmin województwa małopolskiego wydano 1091 decyzji o ustaleniu lokalizacji inwestycji celu publicznego, tj. o ponad dwukrotnie mniej niż w 2004 r. Najwięcej decyzji wydano na terenie miast na prawach powiatu (481), a następnie gmin miejsko-wiejskich (308) i wiejskich (241) (tabela 3).

\section{Podsumowanie}

Na podstawie przeprowadzonych badań postępy w pracach planistycznych w województwie małopolskim można ocenić pozytywnie. Dane wskazują, że w 2011 r. 70,3\% gmin województwa małopolskiego posiadało studium uwarunkowań i kierunków zagospodarowania przestrzennego gminy. Jest to mniej aniżeli w 2004 r., jednak w ok. 29\% gmin dokumenty te były aktualizowane, co świadczy 
o reagowaniu władz na zmiany procesów przestrzennych zachodzących w gminach. Do pożądanych cech stanu zaawansowania prac planistycznych należy wzrost udziału powierzchni pokrytych planami miejscowymi. Pomimo braku obligatoryjności opracowania miejscowych planów zagospodarowania przestrzennego dla obszaru w granicach administracyjnych gmin można zauważyć, że w analizowanych dwóch okresach na terenie gmin województwa małopolskiego wzrosło pokrycie obszarów objętych planami prawie dwukrotnie i osiągnęło poziom $63,2 \%$ ogólnej powierzchni Małopolski. Warto wskazać, że średnia powierzchnia planu miejscowego dla Małopolski wzrosła z 327 ha w 2004 r. do 484 ha w 2011 r. Otrzymane wyniki badań pokazują również, że w województwie małopolskim w okresie przeprowadzonej analizy odsetek gmin z miejscowymi planami zagospodarowania przestrzennego opracowanymi dla powierzchni większej niż 90\% znacznie wzrósł, tj. z 9\% do 57\%. Należy jednak zaznaczyć, że 2011 r. w skali całego województwa obserwuje się spadek powierzchni objętej sporządzanymi planami miejscowymi w stosunku do 2004 r. (o 52\%). Pozytywny jest jednak fakt, że wzrósł wskaźnik odnoszący się powierzchni planów w trakcie sporządzania w miastach na prawach powiatu. Równocześnie w badanym okresie spadła liczba gmin nieposiadających planów miejscowych (z 28 do 15).

Na podstawie przeprowadzonych badań można zatem stwierdzić, że wzrosła aktywność władz samorządowych w zakresie planowania przestrzennego. Największe natężenie prac planistycznych miało miejsce w gminach wiejskich położonych w sąsiedztwie dużego miasta oraz obszarach atrakcyjnych dla nowych inwestycji i budownictwa mieszkaniowego.

\section{Literatura}

Markowski T., Zuber P. [2011], System planowania przestrzennego i jego rola w strategicznym zarzadzaniu rozwojem kraju, Studia KPZK PAN, Warszawa, t. CXXXIV.

Niewiadomski Z. [2009], Planowanie i zagospodarowanie przestrzenne - komentarz, Wydawnictwo C.H. Beck, Warszawa.

Raport o stanie i uwarunkowaniach prac planistycznych $w$ gminach $w 2004$ roku, Ministerstwo Infrastruktury, http://www.transport.gov.pl/2-48edcaaad83e1-1789468-p_1.htm (data dostępu: czerwiec 2012).

Raport o stanie i uwarunkowaniach prac planistycznych $w$ gminach $w 2011$ roku, Ministerstwo Infrastruktury, http://www.transport.gov.pl/2-48edcaaad83e1-1789468-p_1.htm (data dostępu: czerwiec 2012).

Raport o stanie miasta [2011], Biuro Planowania Przestrzennego Urzędu Miasta Krakowa, www.bip.krakow.pl (data dostępu: czerwiec 2012).

Śleszyński P. i in. [2007], Stan zaawansowania planowania przestrzennego w gminach, IGiPZ PAN, Warszawa.

Ustawa z dnia 27 marca 2003 r. o planowaniu i zagospodarowaniu przestrzennym, Dz.U. z 2012 r., poz. 647, 951, 1445, z 2013 r., poz. 21. 


\section{Planistic Situation in the Małopolskie Voivodeship}

Spatial planning is the major tool used in spatial development policies. Proactive policies facilitate the identification of spatial development trends, spatial development policies as well as implementation procedures. Spatial development policies adopted by municipalities in 1995 formed the basis for a comprehensive system of managing territorial government entities. The comprehensive approach taken by local governments to municipality management, coupled with cooperation with local communities, has lead to municipalities' sustained growth and sustainable development.

Spatial planning in Poland is regulated by the Act of 27 March 2003 on spatial planning and development. Pursuant to its provisions, the spatial planning system is implemented at the municipality, regional and national levels. Responsibility for spatial development is vested in the hands of municipalities. At that level, the legal framework for spatial planning and development is based on the analysis of spatial development conditions and trends as well as local spatial development plans.

The paper presents the efforts made by Małopolska's local authorities in launching local spatial development programmes. The analysis covers 182 municipalities located within the region's administrative boundaries. The paper refers to the statistical analyses published in the annual Report on the status and conditions of municipality planning processes, prepared by the Institute of Geography and Spatial Management of the Polish Academy of Sciences (PAN).

The analysis of the status of spatial management in Małopolska's municipalities is carried out for two years: 2004, when the Ministry of Infrastructure began collecting spatial development data at the municipality level, and 2011, the last year for which research was conducted.

Keywords: spatial planning, local spatial management plans, the study of the conditions and directions of spatial development, Małopolskie Voivodeship. 